\title{
PENGARUH DOSIS PAKAN YANG DICAMPUR PROBIOTIK TERHADAP PERTUMBUHAN DAN KELANGSUNGAN HIDUP BENIH IKAN NILA (Oreochromis niloticus)
}

\author{
Alfinta Lasena, Nasriani, Ad Mahmudy Irdja \\ Program Studi Budidaya Perairan Universitas Muhammadiyah Gorontalo, \\ Gorontalo 9600, Indonesia \\ Email : alfintalasena@gmail.com, nasriani_syam@yahoo.com, adirdja@yahoo.com
}

\begin{abstract}
This research was conducted at the laboratory of Agribusiness Fisheries SMKN 1 Batudaa, Dunggala Village, District Batudaa, Gorontalo in February - March 2016. This study aims to determine the best dose of mixed feed with probiotics for the growth and survival rate of tilapia (Oreochromis niloticus) seed. This study used a complete randomized design with 3 treatments and 3 replications. The result showed that the best treatment is the treatment of $B 10 \%$ dose have resulted absolute length of $4.01 \mathrm{~cm}, a$ weight of 4.614 grams, and the best survival rate of $93.33 \%$.
\end{abstract}

Keywords : Tilapia, Probiotics, Growth, Survival

\begin{abstract}
Abstrak
Penelitian ini dilakukan di Laboratorium Agribisnis Perikanan SMK N 1 Batudaa, Desa Dunggala, Kecamatan Batudaa, Kabupaten Gorontalo pada bulan Februari-Maret 2016. Tujuan penelitian ini adalah untuk mengetahui dosis pakan terbaik yang dicampur dengan probiotik untuk pertumbuhan dan kelangsungan hidup benih ikan nila (Oreochromis niloticus). Sebuah rancangan acak lengkap diaplikasikan dalam penelitian ini dengan tiga perlakuan dan tiga ulangan. Hasil penelitian menunjukkan bahwa perlakuan terbaik adalah perlakuan B dosis $10 \%$ dengan pertumbuhan panjang mutlak sebesar $4,01 \mathrm{~cm}$ dan berat mutlak sebesar 4,614 gram serta kelangsungan hidup terbaik adalah 93,33\%.
\end{abstract}

Kata kunci Ikan Nila, Probiotik, Pertumbuhan, kelangsungan hidup

\section{PENDAHULUAN}

Ikan Nila (Oreochromis niloticus) atau juga disebut ikan tilapia merupakan salah satu jenis ikan air tawar introduksi yang mempunyai nilai ekonomis cukup tinggi di beberapa daerah Asia termasuk di Indonesia. Pertama kali ikan Nila didatangkan ke
Indonesia pada tahun 1969. Sejak saat itu, perkembangan budidaya ikan Nila menjadi sangat pesat. Hal tersebut tidak lain karena ikan Nila mempunyai kemampuan adaptasi yang relatif baik terhadap lingkungan. Selain itu, ikan Nila juga mudah dipijahkan sehingga 
mendukung pengembagan usaha budidaya di masyarakat.

Perkembangan budidaya ikan Nila sebagai salah satu komoditas perikanan air tawar mulai menjadi kegiatan agribisnis yang cukup menjanjikan. Hal itu mulai disadari dan digarap dengan baik sejak tahun 1990an. Sejak itu, ikan nila sudah mulai marak diperkenalkan kepada masyarakat dan sudah banyak yang membudidayakannya. Salah satu budidaya kegiatan agribisnis ikan nila adalah Jawa Barat (Nugroho, 2013).

Ikan Nila hidup di perairan tawar hampir di seluruh Indonesia. Jenis ikan ini sebenarnya bukan ikan asli Indonesia. Habitat asli ikan Nila adalah di sungai Nil dan daerah perairan di sekitarnya. Ikan Nila masuk ke Indonesia pada tahun 1969 didatangkan oleh Balai Penelitian Perikanan Air Tawar (BPPAT) Bogor dari Taiwan dan mulai disebarkan ke beberapa daerah di Indonesia. Nila adalah nama khas Indonesia yang diberikan pemerintah melalui Direktur Jenderal Perikanan.

Ikan Nila (Oreochromis niloticus) merupakan ikan ekonomis penting sebagai ikan konsumsi. Ikan ini memiliki daging yang tebal sehingga berpotensi untuk dijadikan sebagai komoditi ekspor dalam bentuk fillet ikan. Produsen terbesar nila di dunia adalah Cina dengan memasok hampir setengah dari kebutuhan pasar nila Amerika diikuti oleh Taiwan dan Vietnam. Berdasarkan data Kementerian Kelautan dan Perikanan
(KKP) pada tahun 2014, menargetkan peningkatan produksi ikan nila sebesar 1.25 juta ton.

Saat ini jenis ikan nila (Oreochromis niloticus) merupakan salah satu ikan air tawar yang sangat digemari oleh masyarakat, sehingga dijadikan peluang bagi petani ikan untuk meningkatkan produktivitas kolamnya. Oleh karena itu, ketersediaan ikan nila ukuran konsumsi perlu ditingkatkan. Upaya untuk memenuhi kebutuhan pasar ikan nila dapat dimulai dengan melakukan penelitian mengenai pakan alternatif sebagai upaya untuk memacu laju tumbuh dan efisiensi usaha. Pakan yang akan dihasilkan diharapkan dapat memanfaatkan ketersediaan bahan lokal dan memiliki kualitas nutrisi yang baik.

Untuk itu, dalam rangka memenuhi kebutuhan sebagai salah satu komoditi sumber protein hewani, diperlukan usaha budidaya ikan nila secara intensif. Namun, kendala yang sering dihadapi yaitu tingginya nilai feeding rate $(F R)$ pada ikan nila yaitu sebesar 4 hingga $6 \%$ dari berat bobot ikan, 5 sampai 20 gram yang tidak sebanding dengan pertumbuhan ikan Nila, sehingga menyebabkan pakan yang diberikan menjadi tidak seimbang. Padahal pakan merupakan input produksi budidaya yang sangat menentukan tingkat pertumbuhan ikan (Widiyati dan Sunarno, 2010).

Nilai $F R$ yang tinggi dan tidak sebanding dengan pertumbuhan ikan nila salah satunya disebabkan oleh 
rendahnya kemampuan daya cerna pakan oleh ikan. Pertumbuhan sangat tergantung dengan kandungan protein dalam pakan, namun ikan tidak hanya memanfaatkan protein untuk pertumbuhan tetapi juga sebagai sumber energi. Salah satu pendekatan yang dapat dilakukan untuk mengatasi masalah tersebut yaitu dengan penambahan probiotik pada pakan komersial. Probiotik adalah bahan makanan yang tidak dapat dicerna yang menguntungkan inang yang secara selektif merangsang pertumbuhan atau aktivitas satu atau sejumlah bakteri dalam usus besar (Ringo et al., 2010).

Putra (2010) dan Putra et al., (2015) melaporkan bahwa penambahan probiotik dalam pakan telah meningkatkan jumlah populasi bakteri dibandingkan dengan perlakuan lainnya sehingga diduga menyebabkan aktivitas enzim dalam pencernaan dan kecernaan pakan meningkat. Beberapa probiotik telah digunakan pada kegiatan akuakultur dan telah berperan dalam meningkatkan pertumbuhan, tingkat kelangsungan hidup, kecernaan, efisiensi pakan, sistem kekebalan tubuh dan komposisi bakteri yang menguntungkan (probiotik) dalam saluran pencernaan ikan

Sudiarto (2013), menyatakan bahwa dosis pemberian probiotik terbaik adalah $1 \%$ yang diformulasikan dalam pakan terhadap pertumbuhan ikan nila (Oreochromis niloticus). Penelitian sebelumnya telah membuktikan bahwa penggunaan probiotik mampu memberikan keuntungan pada budidaya ikan nila antara lain meningkatkan sistem imun dan resistensi terhadap penyakit meningkatkan pertumbuhan, dan meningkatkan tingkat kelangsungan hidup ikan.

\section{METODE PENELITIAN}

Penelitian ini dilaksanakan dari bulan Februari sampai dengan Maret 2016 di Laboratorium Agribisnis Perikanan SMK N 1 Batudaa, Desa Dunggala, Kecamatan Batudaa, Kabupaten Gorontalo, Provinsi Gorontalo.

Wadah yang digunakan dalam penelitian adalah akuarium ukuran $60 \times 40 \times 40 \mathrm{~cm}$ sebanyak sembilan buah yang dilengkapi dengan selang aerasi, batu aerasi, dan blower yang digunakan untuk mensuplai oksigen ke dalam media pemeliharaan benih ikan nila.

Hewan uji yang digunakan dalam penelitian ini adalah benih ikan Nila (Oreochromis niloticus) yang diperoleh dari Balai Pengembangan Budidaya Ikan Air Tawar (BPBIAT) Provinsi Gorontalo. Benih ikan nila yang digunakan berukuran 3 sampai $3.4 \mathrm{~cm}$ dengan berat 1.345 hingga 1.980 gram sebanyak 135 ekor.

\section{Parameter Pengamatan \\ Pertumbuhan Mutlak}

1. Pertumbuhan panjang mutlak 
Perhitungan pertambahan Lo = Panjang awal $(\mathrm{cm})$

panjang mutlak benih ikan nila menurut $\mathrm{H}=$ Lama pemeliharaan (hari)

Effendie (1997) adalah sebagai berikut:

$$
\mathrm{L}=\mathrm{L}_{\mathrm{t}}-\mathrm{L}_{0}
$$

\section{Keterangan:}

$\mathrm{L}=$ Pertumbuhan panjang mutlak ikan (cm)

$\mathrm{Lt}=$ Panjang ikan pada waktu $\mathrm{t}(\mathrm{cm})$

Lo $=$ Panjang ikan pada awal penelitian $(\mathrm{cm})$

\section{Pertumbuhan Berat mutlak}

Perhitungan pertambahan berat mutlak benih ikan nila menurut Effendie (1997) adalah sebagai berikut:

$$
\mathrm{W}=\mathrm{W}_{\mathrm{t}}-\mathrm{W}_{0}
$$

Keterangan:

$\mathrm{W}=$ Pertambahan bobot ikan (gr)

$\mathrm{Wt}=$ Berat akhir ikan pada waktu ke-t (gr)

Wo = Berat awal ikan (gr)

\section{Pertumbuhan Harian}

1. Pertumbuhan panjang harian Perhitungan

Panjang Harian atau Average Daily Growth (ADG) menurut Effendie (1997) adalah sebagai berikut:

$$
A D G=\frac{L t-L o}{H}
$$

Keterangan:

$\mathrm{Lt}=$ Panjang akhir $(\mathrm{cm})$

2. Pertumbuhan Berat Harian

Perhitungan Pertambahan Berat Harian atau Average Daily Growth (ADG) menurut Effendie (1997) adalah sebagai berikut:

$$
A D G=\frac{W t-W o}{H}
$$

Keterangan:

$\mathrm{Wt}=$ Berat akhir (gr)

Wo = Berat awal (gr)

$\mathrm{H} \quad$ = Lama pemeliharaan (hari)

\section{Kelangsungan Hidup}

Kelangsungan hidup atau survival rate (SR) adalah persentase jumlah biota yang hidup pada akhir waktu

tertentu. Perhitungan rumus kelangsungan menurut Goddaard (1996) dalam Tarigan (2014) adalah sebagai berikut:

$$
\mathrm{SR}=\frac{\mathrm{N}_{\mathrm{t}}}{\mathrm{N}_{0}} \times 100 \%
$$

Keterangan:

SR = Tingkat Kelangsungan Hidup (\%)

$\mathrm{Nt}=$ Jumlah Ikan pada waktu ke-t (ekor)

No $=$ Jumlah ikan pada awal penelitian (ekor)

Food Convertion Ratio (FCR) 
Menurut Effendie (1997), rumus

FCR sebagai berikut:

$$
\mathrm{FCR}=\frac{F}{(W t+D)-W o}
$$

Keterangan:

F : Jumlah pakan yang dihabiskan selama penelitian

Wt : Bobot boimassa hewan uji pada akhir pemeliharaan

D : Bobot biomassa hewan uji yang mati

Wo : Bobot biomassa hewan uji pada awal pemeliharaan

\section{Analisis Data}

Untuk mengetahui adanya pengaruh perbedaan dosis pakan yang dicampur dengan probiotik terhadap pertumbuhan dan kelangsungan hidup benih ikan nila, maka data dianalisa dengan menggunakan model rancangan acak lengkap (RAL).

Data yang diperoleh meliputi pertumbuhan mutlak, pertumbuhan harian, survival rate dan Food convertion ratio dihitung dengan menggunakan analisis sidik ragam (ANOVA). Analisis Sidik Ragam (ANOVA) satu arah dengan melakukan uji $\mathrm{F}$.

Menurut Gaspersz (1994) rumus rancangan acak lengkap adalahsebagai berikut:

$$
Y_{i j}=\mu+\tau_{i}+\varepsilon_{i j}
$$

Keterangan:

$\mathrm{Y}_{\mathrm{ij}}=$ Pengamatan dari perlakuan ke i ulangan ke j

$\mu=$ Nilai tengah dari seluruh perlakuan

$\tau_{1}=$ Pengaruh perlakuan ke $\mathrm{i}$

$\varepsilon_{\mathrm{ij}}=$ Galat perlakuan ke $\mathrm{i}$ ulangan ke $\mathrm{j}$

$i=\operatorname{Perlakuan}(A, B, C)$

$\mathrm{j}=$ Ulangan $(1,2,3)$

\section{HASIL DAN PEMBAHASAN}

\section{Pertumbuhan Panjang Mutlak}

Hasil perhitungan panjang mutlak benih ikan Nila sesuai perlakuan pemberian dosis pakan berbeda yang dicampur dengan probiotik selama 28 hari, menunjukkan pertumbuhan panjang mutlak seperti yang terlihat pada Gambar 1.

Berdasarkan Gambar 1, terlihat jelas bahwa perlakuan B (dosis 10\%) memiliki pertumbuhan panjang mutlak tertinggi dengan panjang mutlak 4.01 $\mathrm{cm}$, kemudian disusul oleh perlakuan $\mathrm{C}$ (dosis 5\%) dengan panjang mutlak 3.22 $\mathrm{cm}$, dan perlakuan A (dosis15\%) dengan panjang mutlak terendah yaitu $2.69 \mathrm{~cm}$.

Hasil terbaik terjadi pada perlakuan B (dosis $10 \%+5 \mathrm{ml}$ probiotik) karena jumlah pakan yang diberikan memenuhi kebutuhan benih ikan nila untuk bertahan hidup dan melakukan aktivitas lain seperti bertumbuh. Sementara pada perlakuan C (dosis $5 \%+5 \mathrm{ml}$ probiotik) belum efektif untuk pertumbuhan benih ikan nila. 


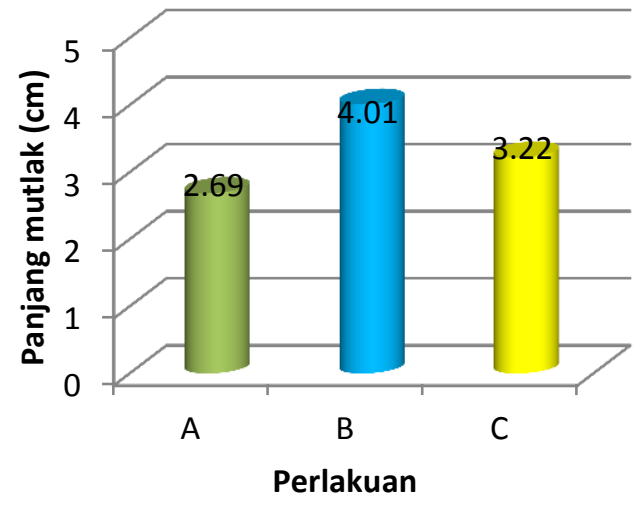

Gambar 1. Grafik Pertumbuhan Panjang Mutlak Benih Ikan Nila

Hal tersebut dapat terlihat dari pertumbuhan panjang mutlak benih ikan nila yang lebih rendah dibandingkan pada perlakuan B. Hal tersebut disebabkan karena pakan yang diberikan hanya cukup untuk proses metabolisme dan aktivitas lain sehingga hanya tersisa sedikit untuk bertumbuh.Hal ini sesuai dengan pernyataan Damayanti dan Saopadi (2012), bahwa ikan akan mengkonsumsi pakan hingga akan memenuhi kebutuhan energinya, sebagian besar pakan digunakan untuk proses metabolisme dan sisanya digunakan untuk beraktifitas lain seperti pertumbuhan. Pada perlakuan pakan A (kontrol) terlihat pertumbuhan benih ikan nila yang lebih rendah dibandingkan dengan benih ikan nila yang mengkonsumsi pakan berprobiotik. Perbedaan pertumbuhan panjang mutlak yang diperoleh dari masing-masing perlakuan menunjukkan bahwa pakan berprobiotik secara efektif dapat membantu mempercepat pertumbuhan benih ikan nila.

\section{Pertumbuhan Berat Mutlak}

Perlakuan pemberian dosis pakan berbeda yang dicampur probiotik pada benih ikan nila selama 28 hari menghasilkan rata-rata pertumbuhan berat mutlak yang berbeda. Hal ini dapat dilihat secara jelas pada Gambar 2. Pemberian pakan dengan dosis $10 \%$ dari bobot tubuh memiliki karena semakin efektif jumlah pakan pertumbuhan berat mutlak terbaik yang tersedia dalam wadah

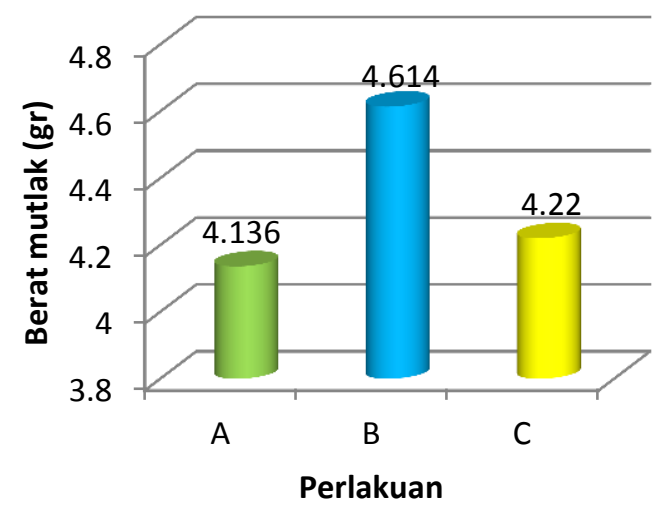

Gambar 2. Grafik Pertumbuhan Berat Mutlak Benih Ikan Nila

pemeliharaan maka peluang dikonsumsinya pakan tersebut akan semakin tinggi, sehingga menyebabkan terjadinya pertumbuhan benih ikan nila yang semakin tinggi pula. Hal ini diperkuat dengan pernyataan Djajasewaka (1985) dalam Cahyoko et al., (2011), pemberian pakan yang sesuai dengan kebutuhan selain dapat menjamin kehidupan ikan juga dapat mempercepat pertumbuhannya. Sementara pemberian pakan dengan dosis $5 \%$ dari bobot tubuh memiliki pertumbuhan tertinggi kedua karena jumlah pakan yang tersedia dalam 
wadah pemeliharaan sebagian besar habis terpakai untuk metabolisme tubuh dan hanya tersisa sedikit untuk pertumbuhan sehingga menyebabkan terjadinya pertumbuhan benih ikan nila yang lambat. Sementara itu pemberian pakan dengan dosis $15 \%$ non probiotik memberikan pertumbuhan bobot tubuh benih ikan nila yang lebih rendah dibandingkan pakan berprobiotik.

Pertumbuhan berat mutlak benih ikan nila dari masing-masing perlakuan memberikan hasil yang berbeda. Adanya perbedaan pertambahan berat mutlak dari ketiga perlakuan dosis pakan yang diberikan menunjukkan bahwa perlakuan di atas memberikan respon yang berbeda-beda.

Perlakuan B memperlihatkan pertumbuhan berat yang tertinggi dibandingkan perlakuan $\mathrm{A}$ dan $\mathrm{C}$. Perbedaan pertumbuhan dari ketiga dosis pakan tersebut dipengaruhi oleh komponen yang terdapat dalam pakan. Pakan berprobiotik (perlakuan B dan C) memiliki pertumbuhan bobot tubuh yang lebih tinggi dibandingkan pakan non probiotik (perlakuan A). Hal ini disebabkan karena pakan pada perlakuan $\mathrm{B}$ dan $\mathrm{C}$ memiliki tambahan vitamin dan mineral dari probiotik yang ditambahkan. Menurut Yanti et al., (2013), komponen lain yang juga dibutuhkan dalam pakan yaitu vitamin dan mineral dalam jumlah yang kecil, namun kehadirannya dalam pakan juga penting karena dibutuhkan tubuh ikan untuk tumbuh dan menjalani beberapa fungsi tubuh. Ikan akan mengkonsumsi pakan hingga akan memenuhi kebutuhan energinya, sebagian besar pakan digunakan untuk proses metabolisme dan sisanya digunakan untuk beraktifitas lain seperti pertumbuhan (Subamia et al., 2003).

\section{Pertumbuhan Harian (ADG)}

Pertumbuhan harian panjang dan berat benih ikan nila (Oreochromis niloticus) selama 28 hari dengan menggunakan tiga perlakuan dosis pakan berbeda yang dicampur probiotik yakni perlakuan A (15\%), perlakuan B (10\%), dan perlakuan C (5\%) secara jelas dapat dilihat pada Tabel 1.

Berdasarkan data pertumbuhan harian panjang dan berat benih ikan nila terlihat bahwa pertumbuhan berat benih ikan nila lebih tinggi dari pertumbuhan panjang. Hal ini menunjukkan bahwa pemberian pakan dengan dosis berbeda yang dicampur probiotik menghasilkan pertumbuhan berat yang lebih tinggi dibandingkan dengan pertumbuhan panjang. Menurut Islaminingrum (2011) dalam Mashuri et al., (2012) bahwa hubungan panjang dan berat yang terjadi pada ikan, ada yang bersifat allometrik positif yang menunjukkan bahwa pertumbuhan berat ikan lebih cepat dari pada pertumbuhan panjangnya dan allometrik negatif yang menunjukkan pertumbuhan panjang ikan lebih cepat dari pada pertumbuhan beratnya. Pertumbuhan Harian panjang dan berat benih ikan nila selama penelitian menunjukkan angka pertumbuhan yang besar karena dipengaruhi oleh 
penambahan probiotik pada pakan benih ikan nila.

Hasil perhitungan pertumbuhan harian rata-rata panjang dan berat menunjukkan bahwa perlakuan $B$

Tabel 1 Pertumbuhan Panjang dan Berat Harian Benih Ikan Nila

\begin{tabular}{ccc}
\hline \multirow{2}{*}{ Perlakuan } & \multicolumn{2}{c}{ Pertumbuhan Harian (ADG) } \\
\cline { 2 - 3 } & Panjang (cm) & Berat (gram) \\
\hline A & 0.096 & 0.148 \\
B & 0.143 & 0.165 \\
C & 0.115 & 0.151 \\
\hline
\end{tabular}

Sumber : Hasil olahan data primer

(dosis pakan $10 \%+5 \mathrm{ml}$ probiotik) memiliki pertumbuhan harian tertinggi kemudian disusul dengan perlakuan $\mathrm{C}$ (dosis $5 \%+5 \mathrm{ml}$ probiotik), dan perlakuan A (dosis $15 \%$ non probiotik) menunjukkan angka pertumbuhan terendah.

Arisma (2004) dalam Wijayanti (2010), menyatakan bahwa pertumbuhan dipengaruhi oleh sumber energy dari pakan yang tersedia. Sumber energi tersebut berupa karbohidrat, lemak, dan protein. Sumber energi nonprotein (Karbohidrat dan lemak) yang tepat dalam pakan dapat mengurangi penggunaan protein sebagai sumber energy (Suhenda $d k k$. 2003 dalam Wijayanti (2010). Jika sumber energi nonprotein cukup, maka fungsi protein untuk pertumbuhan dapat terlaksana (Arisma, 2004 dalam Wijayanti, 2010).

\section{Kelangsungan Hidup}

Hasil perhitungan kelangsungan hidup benih ikan nila (Oreochromis niloticus) sesuai perlakuan pemberian dosis pakan berbeda yang dicampur dengan probiotik, menunjukkan kelangsungan hidup seperti yang terlihat pada Gambar 3.

Berdasarkan data yang disajikan pada gambar 3 dapat diketahui bahwa kelangsungan hidup benih ikan nila berbeda-beda pada tiap perlakuan. Kelangsungan hidup tertinggi diperoleh pada benih ikan nila yang diberi pakan B yaitu sebesar $93.33 \%$ sedangkan yang terendah secara berturut-turut adalah yang diberi pakan $\mathrm{C}$ dan $\mathrm{A}$.

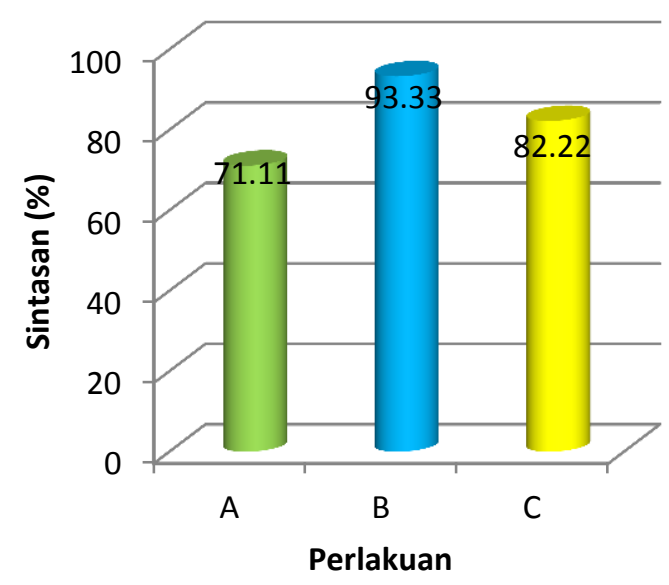

Gambar 3. Kelangsungan Hidup Benih Ikan Nila

Tingginya kelangsungan hidup benih ikan nila yang diberi pakan berprobiotik (perlakuan B dan C) dibandingkan dengan pakan non probiotik (perlakuan A) dipengaruhi oleh kandungan nutrisi pakan berprobiotik yang cukup untuk mendukung kebutuhan pokok ikan. Hal ini sejalan dengan pernyataan Harun (2007), bahwa kecukupan jumlah dan jenis yang cukup untuk mendukung 
kebutuhan pokok ikan dapat menunjang kehidupan ikan.

Yustina (2003) dalam Rabiati et al., (2013), menyatakan kematian larva yang tinggi disebabkan larva sudah kehabisan cadangan makanan berupa kuning telur, sedangkan pakan alami yang tedapat didalam media hidupnya tidak sesuai dengan kebutuhan serta makanan tidak sesuai dengan jenis, ukuran dan jumlah.

\section{Rasio Konversi pakan ( $F C R$ )}

Pada penelitian ini, kebutuhan pakan benih ikan nila (Oreochromis niloticus) dihitung berdasarkan hasil penimbangan berat benih ikan nila (Oreochromis niloticus) per satu minggu. Persentase pakan yang diberikan selama penelitian sesuai dengan dosis masing-masing perlakuan. Untuk perlakuan A (Dosis $15 \%$ ) perlakuan $\mathrm{B}$ (Dosis 10\%) dan perlakuan $C$ (Dosis 5\%) dari bobot tubuh benih ikan nila. Hasil perhitungan konversi pakan benih ikan nila (Oreochromis niloticus) sesuai perlakuan pemberian dosis pakan berbeda yang dicampur dengan probiotik terlihat pada Gambar 4. Pemberian dosis pakan yang berbeda pada benih ikan nila (Oreochromis niloticus), menunjukkan tingkat pemberian pakan yang berbeda pula. Tingkat pemberian pakan tertinggi ditunjukan pada perlakuan $A$ yaitu 3,144 gram, kemudian yang kedua ditunjukan pada perlakuan B yaitu sebesar 1,920 gram, dan pemberian pakan yang terendah ditunjukan pada perlakuan C yaitu sebesar 1,178 gram. Semakin rendah nilai FCR berarti

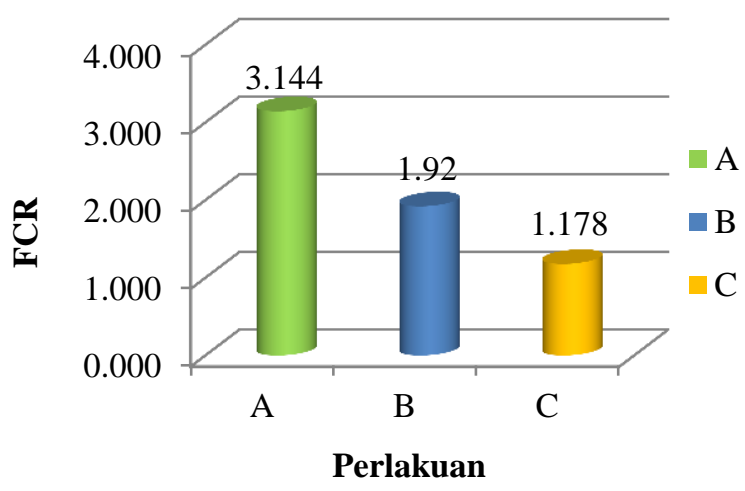

Gambar 4. Konversi Pakan Benih Ikan Nila

semakin baik pakan yang diberikan. Semakin rendah nilai FCR berarti semakin baik pakan yang diberikan. Nilai FCR terbaik terdapat pada perlakuan C (dosis 5\%) sebesar 1.178 hal ini berarti untuk menghasilkan 1 gram daging dibutuhkan pakan sebanyak 1.178 gram. Menurut Effendie (1979), semakin rendah nilai konversi pakan, semakin sedikit yang dibutuhkan untuk menghasilkan $1 \mathrm{~kg}$ daging ikan. Artinya, semakin efisien pakan tersebut diubah menjadi daging.

\section{Kualitas Air}

Kualitas air merupakan faktor yang sangat penting dalam budidaya ikan karena diperlukan sebagai media hidup. Air sebagai lingkungan tempat hidup organisme perairan harus mampu mendukung kehidupan dan pertumbuhan dari organisme tersebut. Hasil pengukuran kualitas air selama pemeliharaan benih ikan nila (Oreochromis niloticus) menunjukkan 
bahwa kisaran yang diperoleh masih berada pada batas yang baik bagi kehidupan benih. Data kualitas air dapat dilihat pada Tabel 2 .

Pengukuran kualitas air dilakukan setiap seminggu sekali dengan menggunakan alat ukur $\mathrm{pH}$ meter dan termometer. Pengukuran kualitas air selama masa pemeliharaan dilakukan setiap seminggu sekali, kualitas air yang diukur yaitu suhu dan $\mathrm{pH}$. Sumber air yang digunakan adalah air tawar yang berasal dari Laboratorium Agribisnis Perikanan SMK N 1 Batudaa, air tersebut

Tabel 2. Parameter kualitas air pemeliharaan benih ikan nila

\begin{tabular}{ccc}
\hline \multirow{2}{*}{ Perlakuan } & \multicolumn{2}{c}{ Parameter } \\
\cline { 2 - 3 } & Suhu $\left({ }^{\circ} \mathrm{C}\right)$ & $\mathrm{pH}$ \\
\hline $\mathrm{A}$ & $28-29$ & $6.8-7$ \\
$\mathrm{~B}$ & $27-28$ & $6.8-7$ \\
$\mathrm{C}$ & $27-29$ & $6.8-7$ \\
\hline
\end{tabular}

Sumber : Hasil olahan data primer

kemudian diendapkan dalam sebuah wadah plastik sehingga dapat digunakan untuk pemeliharaan benih ikan nila.

Air yang digunakan selama pemeliharaan benih ikan nila didukung dengan diterapkan sistem aerasi selama 24 jam, selain itu juga dilakukan pembersihan dasar wadah dengan cara dishipon. Penyiphonan dilakukan setiap pagi dan sore hari, jumlah air yang diambil dalam kegiatan penyiponan sebanyak $25 \%$ dari total air. Kegiatan pergantian air dilakukan setelah proses pengukuran panjang dan berat, dengan cara membuang $70 \%$ dari total air yang ada diwadah pemeliharaan kemudian menambahkan dengan air baru.

Beberapa faktor lingkungan di dalam air yang berpengaruh terhadap kehidupan ikan antara lain suhu, derajat keasaman $(\mathrm{pH})$ dan lain sebagainya. Suhu air selama penelitian berkisar antara $27-29^{\circ} \mathrm{C}$. Hal itu menunjukkan bahwa media pemeliharaan sesuai dengan pendapat Djokosetiyanto, et al., (2005), yang menyatakan suhu air yang baik untuk pemeliharaan ikan patin siam berkisar antara $26-30^{\circ} \mathrm{C}$. Hubungan antara suhu dengan pertumbuhan ikan menurut Huet (1971) dalam Syamsunarno (2008), yaitu adanya pertumbuhan yang kecil atau tidak ada sama sekali di bawah suhu tertentu $\left(20^{\circ} \mathrm{C}\right)$. Selanjutnya, pertumbuhan meningkat seiring dengan meningkatnya suhu sampai mencapai titik maksimum $\left(30^{\circ} \mathrm{C}\right)$, dan menurun kembali atau bahkan menjadi negatif (letal) pada suhu di atas titik maksimum $\left(33^{\circ} \mathrm{C}\right)$. Dengan demikian, kisaran suhu air pada media penelitian tersebut masih dalam batas yang layak dalam mendukung pertumbuhan benih ikan nila.

\section{KESIMPULAN DAN SARAN \\ Kesimpulan}

1. Dosis pakan berbeda yang dicampur probiotik berpengaruh sangat nyata terhadap pertumbuhan dan kelangsungan hidup benih ikan nila (Oreochromis niloticus).

2. Dosis pakan terbaik yang dicampur probiotik untuk pertumbuhan dan 
kelangsungan benih ikan nila adalah sebanyak $10 \%$ dari berat biomassa.

\section{Saran}

Perlu dilakukan penelitian lanjutan mengenai penggunaan probiotik lain dan Penggunaan probiotik disarankan diaplikasikan pada budidaya ikan nila untuk menurunkan penggunaan pakan yang berlebih dan pemanfaatan nutrisi dalam pakan yang optimal.

\section{DAFTAR PUSTAKA}

Cahyoko, Y., Arif , M., dan Pertiwi, K. 2011. Pengaruh Pemberian Pakan Buatan, Pakan Alami, dan Kombinasinya terhadap Pertumbuhan,

Rasio Konservasi Pakan dan Tingkat Kelulushidupan Ikan Sidat (Anguilla Bicolor). Jurnal IImiah Perikanan dan Kelautan. Fakultas Perikanan dan Kelautan Universitas Airlangga Damayanti, A., Amir, S., dan Saopadi. 2012. Frekuensi Pemberian Pakan Optimum Menjelang Panen Pada Ikan Nila (Oreochromis niloticus). Jurnal Perikanan Unram. Program studi budidaya perairan. Universitas Mataram.

Djokosetiyanto, D., Dongoran, R. K., dan Supriyono, E. 2005. Pengaruh alkalinitas terhadap kelangsungan hidup dan pertumbuhan larva ikan patin siam (Pangasius sp.). Jurnal akuakultur Indonesia. Fakultas perikanan dan ilmu kelautan. Institut Pertanian Bogor. Bogor.

Effendie, M.I., 1979. Metode Biologi Perikanan. Cetakan Pertama. Bogor. Yayasan Dewi Sri.

Effendie, M.I., 1997. Biologi Perikanan. Yogyakarta. Yayasan Pustaka Nusantara. 163 hal.

Gaspersz, V. 1994. Metode Perancangan Percobaan. Cetakan Kedua. CV. Armico. Bandung.

Harun. 2007. Pengaruh Kadar Protein dan Nisbah Energi Protein Pakan Berbeda Terhadap Kinerja Pertumbuhan Benih Ikan Batak (Labeobarbus soro). Tesis. Institut Pertanian Bogor.

Mashuri, Sumarjan, dan Abidin, Z., 2012. Pengaruh Jenis Pakan Yang Berbeda Terhadap Pertumbuhan Belut Sawah (Monopterus albus zuieum) The Effect Of Different Feed Types On The Growth Of Eels (Monopterus albus zuieuw). Jurnal Penelitian. Fakultas Pertanian Universitas Mataram

Nugroho, Estu. 2013. Nila Unggul\#1Cet.1. Penebar Swadaya. Jakarta 
Putra AN, Utomo NBP dan Widanarni. 2015. Growth Performance of Tilapia (Oreochromis niloticus) Fed with Probiotic, Prebiotic and Synbiotic in Diet. Pakistan Journal of Nutrition 14 (5): 263268.

Putra AN. 2010. Kajian Probiotik dan Sinbiotik untuk Meningkatkan Kenerja Pertumbuhan Ikan Nila (Oreochromis niloticus). TESIS. Bogor: Fakultas Perikanan dan IImu Kelautan, Institut Pertanian Bogor.

Rabiati., Basri. Y dan azrita. 2013. Pemberian Pakan Alami Yang Berbeda Terhadap Laju Sintasan Dan Pertumbuhan Larva Ikan Bujuk (Channa lucius Civier). Jurnal Penelitian. Fakultas Perikanan dan ilmu Kelautan Universitas Bung Hatta.

Ringø E, Olsen RE, Gifstad TØ, Dalmo RA, Amlund H, Hemre GL dan Bakke AM. 2010. Prebiotics in aquaculture: a review. Aquaculture Nutrition 16:117136

Sudiarto AJ, Mustahal dan Putra AN. 2013. Aplikasi Prebiotik pada Pakan Komersial untuk Meningkatkan Kinerja Pertumbuhan pada Ikan Nila (Oreochromis niloticus). Jurnal Perikanan dan Kelautan 4 (4): 229-234

Syamsunarno, M.B. 2008. Pengaruh Rasio Energi-Protein yang Berbeda Pada Kadar Protein
Pakan 30\% Terhadap Kinerja Pertumbuhan Benih Ikan Patin (Pangasius hypophthalmus). Skripsi. Institut Pertanian Bogor. Bogor.

Tarigan, Pindota. 2014. Laju Pertumbuhan dan Kelangsungan Hidup Benih Ikan Botia (Chromobotia macracanthus) dengan Pemberian Pakan Cacing Sutera (Tubifex sp.) yang Dikultur Dengan Beberapa Jenis Pupuk Kandang. Skripsi. Program Studi Manajemen Sumberdaya Perairan. Fakultas Pertanian. Universitas Sumatera Utara.

Widiyati, A dan M. T. D. Sunarno. 2010. Dampak penggunan pakan buatan terhadap keberlanjutan perikanan budidaya di perairan waduk. Badan research kelautan dan perikanan. Bogor.

Wijayanti, K. 2010. Pengaruh Pemberian Pakan Alami Yang Berbeda Terhadap Sintasan dan Pertumbuhan Benih Ikan Palmas (Polypterus senegalus senegalus).

Skripsi. Departemen Biologi Akuakultur. Universitas Indonesia. Depok.

Yanti, Z. Z.A. Muchlisin, Sugito. 2013. Pertumbuhan dan Kelangsungan Hidup Benih Ikan Nila (Oreochromis niloticus) Pada Beberapa Konsentrasi Tepung Daun Jaloh (Salix trasperma) Dalam Pakan. 